\title{
Antineutrofil citoplazmatikus antitest asszociált vasculitisek korszerü kezelése
}

\author{
Szabó Melinda Zsuzsanna dr. - Pálfi Patrícia dr. - Bazsó Anna dr. \\ Poór Gyula dr. - Kiss Emese dr.
}

Országos Reumatológiai és Fizioterápiás Intézet, Budapest

\begin{abstract}
Összefoglaló tanulmányukban a szerzők a vasculitisek nómenklatúrájának és az antineutrofil citoplazmatikus antitest asszociált vasculitisek felosztásának ismertetését követően bemutatják a betegségaktivitás mérésének lehetőségeit (5 tényezős pontrendszer, Birmingham Vasculitis Aktivitás Index), valamint ezek szerepét a terápiás igény meghatározásában. Ismertetik az antineutrofil citoplazmatikus antitest asszociált vasculitisek terápiás algoritmusát, külön részletezve az indukciós és a fenntartó kezelés során használható, több klinikai vizsgálat alapján is sokszor hasonló terápiás értékű gyógyszerek dozírozását, leggyakoribb mellékhatásait, illetve ezek kivédésének lehetőségeit. Kiegészítő terápiaként többek között felhívják a figyelmet a plazmaferézis jelentőségére, illetve a gyógyszeres terápiák sikertelensége esetén szükségessé váló vesetranszplantáció feltételeire, várható kimenetelére. A közleményben ismertetnek számos, jelenleg is folyó klinikai vizsgálatot, amelyek eredményei várhatóan a következő években tovább fogják szélesíteni az antineutrofil citoplazmatikus antitest asszociált vasculitisek terápiás lehetőségeit. Orv. Hetil., 2015, 156(41), $1653-1660$.
\end{abstract}

Kulcsszavak: antineutrofil citoplazmatikus antitest asszociált vasculitis, ciklofoszfamid, tituximab, plazmaferézis

\section{Recent advances in the treatment of antineutrophil cytoplasm antibody associated vasculitides}

The authors review the nomenclature of vasculitides and the classification of antineutrophil cytoplasm antibody associated vasculitides and present the method of measuring disease activity (Five-factor Score, Birmingham Vasculitis Activity Score) and its role in defining therapeutical needs. They discuss the treatment algorithm of antineutrophil cytoplasm antibody associated vasculitides, present the sometimes equipotential medications used during the induction therapy followed by a maintenance regimen, and outline their usage and possible side-effects that may require medical attention. They point out the importance of plasmapheresis as an adjunctive treatment in some cases, as well as indications and possible outcome of kidney transplantation in therapy-resistant cases. Finally, they review several ongoing clinical studies, as their outcome will probably influence therapeutical opportunities of antineutrophil cytoplasm antibody associated vasculitides in the next few years.

Keywords: antineutrophil cytoplasm antibody associated vasculitis, cyclophoshamide, rituximab, plasmapheresis

Szabó, M. Zs., Pálfi, P., Bazsó, A., Poór, Gy., Kiss, E. [Recent advances in the treatment of antineutrophil cytoplasm antibody associated vasculitides]. Orv. Hetil., 2015, 156(41), 1653-1660.

(Beérkezett: 2015. július 29.; elfogadva: 2015. augusztus 27.)

\section{Rövidítések}

AAV = antineutrofil citoplazmatikus antitest asszociált vasculitis; ANCA = antineutrofil citoplazmatikus antitest; anti-PR3ANCA = antiproteináz 3 antineutrofil citoplazmatikus antitest; anti-MPO-ANCA = anti-mieloperoxidáz antineutrofil citoplazmatikus antitest; AZA = azatioprin; BREVAS = klinikai vizsgálat a belimumab hatékonyságának vizsgálatára MPA-ban és GPA-ban; BSR = (British Society for Rheumatology) Brit Reumatológiai Társaság; BVAS $=($ Birmingham Vasculitis Activity Score) Birmingham Vasculitis Aktivitás Index; CHUSPAN 2 = klinikai vizsgálat az azatioprin és a ciklofoszfamid hatékonyságának megítélésére PAN-ban és MPA-ban; EGPA = eozinofil granulomatosus polyangitis; EULAR $=$ (European League Against Rheumatism) Európai Reumaellenes Liga; 
EUVAS $=($ European Vasculitis Study Group) Európai Vasculitis Vizsgálócsoport; EUVAS NORAM = klinikai vizsgálat a methotrexat és a ciklofoszfamid hatékonyságának összehasonlítására AAV-s betegekben; EUVAS-RITUXVAS = nemzetközi, randomizált vizsgálat a rituximab és a ciklofoszfamid/azatioprin hatékonyságának összehasonlítására $\mathrm{AAV}$-s betegekben; FFS $=($ Five-factor Score $)$ öttényezős pontrendszer; FVSG = (French Vasculitis Study Group) Francia Vasculitis Vizsgálócsoport GFR = glomerulusfiltrációs ráta $; \mathrm{GPA}=$ granulomatosus polyangitis; IMPROVE = klinikai vizsgálat a mikofenolát mofetil és az azatioprin remissziófenntartó hatékonyságának összehasonlítására; LAMP-2 = lizoszómaasszociált membránprotein 2; MAINRITSAN = prospektív randomizált kontrollált vizsgálat a rituximab és az azatioprin hatékonyságának összehasonlítására; $\mathrm{MMF}=$ mikofenolát mofetil; $\mathrm{MPA}=$ mikroszkópos polyangitis; MTX = methotrexat; PEXIVAS = randomizált vizsgálat a plazmaferézis és a glükokortikoiddózisok szerepének tisztázására; RAVE = vizsgálat a ciklofoszfamid és a rituximab hatékonyságának összehasonlítására ANCA-asszociált vasculitises betegek remisszióindukciójában; REMAIN = klinikai vizsgálat az azatioprin fenntartó hatékonyságának vizsgálatára; RITAZAREM = randomizált kontrollvizsgálat a rituximab és az azatioprin hatékonyságának összehasonlítására; RTX = rituximab; VCRC = (Vasculitis Clinical Research Consortium) Vasculitis Klinikai Kutató Konzorcium

A szisztémás vasculitisek olyan heterogén betegségcsoport, amelyben közös jellemző az érfal gyulladása. A kórképhez tartozó betegségek klasszifikációja az elmúlt évtizedekben többször változott, jelenleg a 2012es Chapel Hill-i Konszenzuskonferencia kritériumait használjuk a besoroláshoz, a homogén betegségcsoportok kialakításához [1] (1. táblázat). A beosztásban döntő szerepet játszik az érintett erek mérete és a patogenetikai háttér, főként az immunkomplexek jelenléte vagy hiánya. A kisérvasculitiseket további két csoportra bonthatjuk. Az első, immunkomplex-mediált csoportba az antiglomerularis bazálmembrán betegséget, a cryoglobulinaemiás vasculitist, a hypocomplementaemiás urticaria vasculitist és az IgA-vasculitist (Henoch-Schönlein) soroljuk. Ezekben a betegségekben immunglobulin- és/vagy komplementdepozitumok rakódnak le az erek falában. Ezzel ellentétben, a másik csoportban az anti-MPO-, illetve anti-PR3-ANCA jelenléte dominál, és az úgynevezett pauci-immunfolyamatok jellemzik. Az ANCA-asszociált vasculitiseket a klinikai tünetek és az ANCA-specificitás alapján további 3 csoportba soroljuk: 1. granulomatosus polyangitis (GPA, régi nómenklatúra szerint Wegener-granulomatosis), 2. mikroszkópos polyangitis (MPA) és 3. eozinofil granulomatosus polyangitis (EGPA vagy a régi nevezéktan szerint Churg-Strauss-szindróma). A 2. táblázat tartalmazza az egyes csoportok hisztológiai, immunszerológiai és klinikai sajátosságait [2].

Az immunszuppresszív kezelések megkezdése előtt az ANCA-asszociált vasculitises betegek 93\%-a két éven belül meghalt, életkilátásaik a glükokortikoidok 1950-es és a ciklofoszfamid 1970-es megjelenésével lényegesen ja-
1. táblázat |A vasculitisek nómenklatúrája a 2012-es Nemzetközi Chapel Hill-i Konszenzuskonferencia alapján [1]

Nagyérvasculitisek (large vessel vasculitis - LVV)

Takayasu-arteritis (TAK)

Óriássejtes arteritis (giant cell arteritis - GCA)

Közepes méretű erek vasculitise (medium vessel vasculitis - MVV)

Polyarteritis nodosa (PAN)

Kawasaki-betegség (Kawasaki disease - KD)

Kisérvasculitis (small vessel vasculitis $-S V V$ )

ANCA-asszociált vasculitis (AAV)

Mikroszkópos polyangitis (MPA)

Granulomatosus polyangitis (GPA)

Eozinofil granulomatosus polyangitis (EGPA)

Immunkomplex-mediált vasculitis

Antiglomerularis bazálmembrán (anti-GBM) betegség

Cryoglobulinaemiás vasculitis $(\mathrm{CV})$

IgA-vasculitis (Henoch-Schönlein) (IgAV)

Hypocomplementaemiás urticariás vasculitis

(HUV) (anti-Clq-vasculitis)

Közepes méretú erek vasculitise (variable vessel vasculitis - VVV)

Behcet-kór (Behcet's disease - BD)

Cogan-szindróma (CS)

Egy szervet érintő vasculitis (single organ vasculitis - SOV)

Cutan leukocytoclasticus angitis

Cutan arteritis

Primer központi idegrendszeri vasculitis

Izolált aortitis

Egyebek

Szisztémás betegséghez társuló vasculitis

Lupusvasculitis

Rheumatoid vasculitis

Sarcoid vasculitis

Egyebek

Vasculitisek valószínűsíthető eredettel

Hepatitis C-vírus-fertőzéshez asszociált cryoglobulinaemiás vasculitis

Hepatitis B-vírus-fertőzéshez asszociált vasculitis

Szifiliszasszociált aortitis

Gyógyszerasszociált immunkomplex-vasculitis

Gyógyszerasszociált ANCA-asszociált vasculitis

Daganatasszociált vasculitis

Egyebek

LVV $=$ (large vessel vasculitis) nagyérvasculitis; TAK $=$ Takayasu-arteritis; $\mathrm{GCA}=$ (giant cell arteritis $)$ óriássejtes arteritis; $\mathrm{PAN}=$ polyarteritis nodosa; $\mathrm{KD}=$ (Kawasaki disease $)$ Kawasaki-betegség; SVV = (small vessel vasculitis) kisérvasculitis; AAV $=$ ANCA-asszociált vasculitis; $\mathrm{MPA}=$ mikroszkópos polyangitis; $\mathrm{GPA}=$ granulomatosus polyangitis; EGPA = eozinofil granulomatosus polyangitis; anti-GBM = antiglomerularis bazálmembrán betegség; $\mathrm{CV}$ = cryoglobulinaemiás vasculitis; IgAV = IgA-vasculitis (Henoch-Schönlein); HUV = hypocomplementaemiás urticaria vasculitis vagy anti-Clq-vasculitis; $\mathrm{VVV}=($ variable vessel vasculitis) közepes méretú erek vasculitise; $\mathrm{BD}=($ Bechet disease $)$ Bechet-kór; $\mathrm{CS}=$ Cogan-szindróma; $\mathrm{SOV}=$ (single organ vasculitis $)$ egy szervet érintő vasculitis 
2. táblázat |Az ANCA-asszociált vasculitisek felosztása [4]

\begin{tabular}{|c|c|c|c|}
\hline & GPA (Wegener) & MPA & EGPA (Churg-Strauss) \\
\hline Vasculitis jellege & Neutrofildominancia & Neutrofildominancia & Eozinofildominancia \\
\hline Interstitalis eltérés jellege & $\begin{array}{l}\text { Neutrofildominanciájú infiltrátum } \\
\text { és granuloma }\end{array}$ & $\begin{array}{l}\text { Neutrofildominanciájú } \\
\text { infiltrátum, granulomaképződés } \\
\text { nélkül }\end{array}$ & $\begin{array}{l}\text { Eozinofildominanciájú infiltrátum } \\
\text { és granuloma }\end{array}$ \\
\hline PR3-ANCA (cANCA) & $80-90 \%$ & $10-30 \%$ & $1-2 \%$ \\
\hline MPO-ANCA (pANCA) & $5-10 \%$ & $>90 \%$ & $30-70 \%$ \\
\hline Klinikai tünetek gyakorisága & $\begin{array}{l}\text { Felső légút > vese, tüdő > bőr, } \\
\text { szem > mononeuritis multiplex > } \\
\text { GI traktus }\end{array}$ & $\begin{array}{l}\text { Vese > tüdő > bör, mononeuritis } \\
\text { multiplex }\end{array}$ & $\begin{array}{l}\text { Mononeuritis multiplex, bőr, } \\
\text { GI traktus > vese > myocardium }\end{array}$ \\
\hline Differenciáldiagnosztika & Típusos légúti tünetek, granuloma & Előbbiek hiánya, klinikai kép & $\begin{array}{l}\text { Allergiás előzmény, eozinofilia } \\
\text { a vérben és szövetmintában }\end{array}$ \\
\hline
\end{tabular}

EGPA = eozinofil granulomatosus polyangitis; GI = gastrointestinalis; GPA = granulomatosus polyangitis; MPA = mikroszkópos polyangitis; MPO-ANCA = mieloperoxidáz elleni antineutrofil citoplazmatikus antitest; PR3-ANCA = proteináz 3 elleni antineutrofil citoplazmatikus antitest.

vultak [3], ma már az 5 éves túlélés $80 \%$. A diagnózist követő első évben vezető halálokok az infekciók (48\%) és az aktív vasculitis (19\%), majd a későbbiekben a cardiovascularis betegségek (26\%), malignus betegségek (22\%) és az infekciók (20\%) voltak. A túlélés szempontjából szignifikánsan rossz prognosztikai faktorok az alacsony GFR ( $<15 \mathrm{ml} / \mathrm{min})$, a magas életkor, a magas Birmingham Vasculitis Aktivitás Pontszám, az alacsony hemoglobinszint és a magas fehérvérsejtszám [4].

A kezelés megtervezésekor tehát figyelembe kell venni a klasszifikációt, a prognosztikai tényezóket, az etiológiát, a patogenezist, a betegség súlyosságát, a beteg életkorát ahhoz, hogy a lehető legkevésbé toxikus gyógyszerrel tudjunk teljes remissziót elérni és fenntartani.

A betegség súlyosságának megítélésére dolgozott ki a francia Vasculitis Study Group egy öttényezős pontrendszert (Five-factor Score - FFS) [5, 6], amelynek szignifikáns prognosztikai értéke van PAN-ban, MPA-ban és EGPA-ban. Az $1 \mathrm{~g} /$ nap feletti proteinuria, a veseelégtelenség (kreatinin>140 $\mu \mathrm{mol} / \mathrm{l}$ ), a cardiomyopathia, a gastrointestinalis manifesztációk, a központi idegrendszeri érintettség rossz prognosztikai faktorok. Nullás FFS esetén a betegek 11,9\%-a halt meg öt éven belül, míg > 2 FFS-nél 45,95\%-uk. A módosított FFS-kritériumokat 2011-ben publikálták [7], ebbe már belekerült a 65 év feletti életkor, mint további rossz prognosztikai marker, illetve a fül-orr-gégészeti manifesztáció, mint jó prognosztikai tényező GPA-ban és EGPA-ban. Sajnálatos módon a klinikumban az FFS nem terjedt el. Helyette elsősorban a Birmingham Vasculitis Aktivitás Indexet (Birmingham Vasculitis Activity Score - BVAS) (3. táblázat) használjuk a vasculitises betegek kezelési intenzitásának megválasztásához. Ezt 1994-ben szisztémás vasculitisek aktivitásának értékelésére validálták, több alkalommal módosították: 1997-ben azért, hogy az európai utánkövetéses vizsgálatokban is használható legyen [8], 2001-ben pedig, hogy egy GPA-ra specifikus eszközt hozzanak létre [9]. 2009-ben eltávolították a felesleges részeket [10], így az utolsó verzióban 56 vasculitis- manifesztáció szerepel numerikus súlyozással, minden szervrendszernél maximalizálva van az elérhető legmagasabb pontszám.

Pontozni csak az aktív vasculitis okozta tüneteket kell. A pontszámok tükrözik az egyes szervrendszerek és manifesztációk súlyosságát, segítik az új vagy klinikailag romló, azaz immunszuppresszív kezelést, szoros obszervációt igénylő aktív vasculitises esetek azonosítását. A Brit Reumatológiai Társaság utolsó ANCA-asszociált vasculitis kezelési irányelve [11] alapján a BVAS alkalmas a betegség súlyosságának a megállapítására és ezáltal a terápiás igény meghatározására az alábbiak szerint:

1. Aktív betegség, amelyet a különböző vizsgálatok eltérően határoznak meg (például: $B V A S>8$, legalább 1 major vagy 3 minor kritérium teljesül stb.): glükokortikoid mellett ciklofoszfamid- vagy rituximabkezelés megkezdése indokolt, illetve, ha életet, vitális szervet veszélyeztető érintettség nincsen, e helyett methotrexat vagy mikofenolát mofetil adása is szóba jön.

2. Gyógyszeres remisszióban a prednizolon dózisa $<10$ $\mathrm{mg} / \mathrm{nap}$ és a BVAS $\leq 1$ legalább 6 hónapig; a rituximab folytatható vagy váltás történhet azathioprinre, illetve methotrexatra, a glükokortikoiddózis csökkenthetó.

3. Gyógyszermentes remisszió esetén a beteg legalább 6 hónapja kezelés nélkül van.

4. Minor relapsusban $\geq 1$ új vagy romló minor kritérium jelenik meg major kritérium nélkül, olyan betegen, aki korábban remisszióban volt. Gyakran elegendő csak a glükokortikoiddózis emelése az ismételt remisszió eléréséhez.

5. Major relapsus - $\geq 1$-gyel emelkedő major kritériumszám olyan betegen, aki korábban remisszióban volt. Ciklofoszfamid vagy rituximab adása, a glükokortikoiddózis emelése indokolt, a plazmaferézis megfontolandó. A relapsus okát mindenképpen keresni kell, infekció, malignitás lehetősége felmerül.

6. A terápiára nem reagáló, refrakter esetekben a rituximab effektívebb, mint a ciklofoszfamid, szükség esetén 


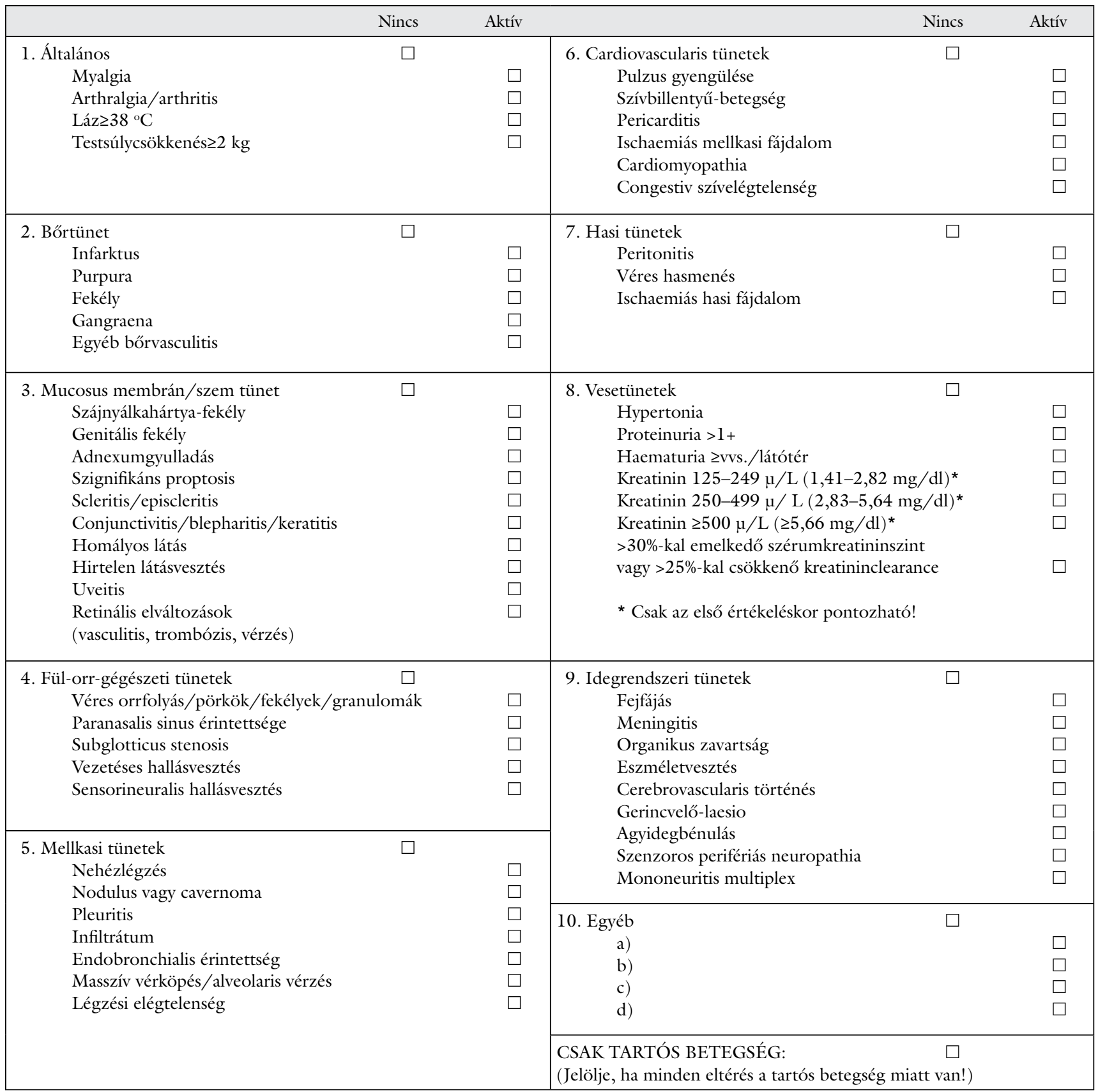

plazmaferézissel kiegészítve. További vizsgálatok elvégzése, a klinikai diagnózis esetleges revideálása szükséges.

A BVAS nagyon hatékony eszköz a vasculitises betegek mindennapi kezelésében, előnye, hogy számszerúleg meghatározza a betegség aktivitását és az egyes szervrendszerek érintettségét, hátránya, hogy a több mint 3 hónapja fennálló, betegségaktivitásban változást nem mutató esetek kezeletlenek maradhatnak vele.

Az ANCA-asszociált vasculitises betegek terápiás ajánlását az EUVAS (European Vasculitis Study Group - Európai Vasculitis Vizsgálócsoport), az EULAR (European League Against Rheumatism - Európai Reumaellenes
Liga) és a BSR (British Society for Rheumatology - Brit Reumatológiai Társaság) dolgozta ki (Hellmich, 2007 [12], Mukhtyar, 2009 [10], Ntatsaki, 2014 - 1. ábra [11]). Minden fontosabb, jelenleg folyó vizsgálat részletei megtalálhatóak az EUVAS (European Vasculitis Study Group - Európai Vasculitis Vizsgálócsoport, www.vasculitis.org), az FVSG (French Vasculitis Study Group - Francia Vasculitis Vizsgálócsoport, www.vascularites.org) és a VCRC (Vasculitis Clinical Research Consortium - Vasculitis Klinikai Kutató Konzorcium, rarediseasenetwork. epi. usf. edu/vcrc/index.htm) weboldalain. 


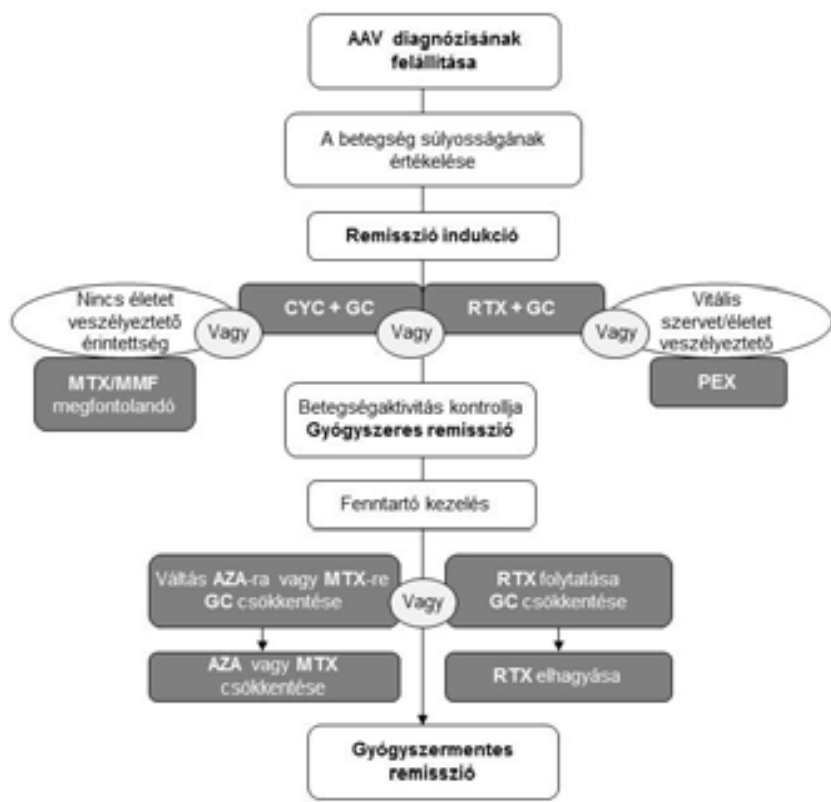

1. ábra

| AAV-k kezelési algoritmusa [11]

\section{Indukciós kezelés}

\section{MPA és EGPA rossz prognózissal és a GPA súlyos/szisztémás formái}

Rossz prognosztikai faktorral (FFS $\geq 1$ ) rendelkező MPAs, illetve EGPA-s, valamint súlyos/szisztémás formával jelentkező GPA-s betegeknek indukciós kezelésként szteroidot és ciklofoszfamidot vagy rituximabot kezdünk. Indukció során a methylprednisolon javasolt dózisa iv. $7,5-15 \mathrm{mg} / \mathrm{kg} 24$ óránként $1-3$ napon át, használatát indokolja, hogy gyors hatású, rövid távon biztonságos. Kontraindikáció lehet az egyre inkább felmerülő kumulatív hatás.

A per os glükokortikoidok ajánlott dózisa naponta egyszeri, reggeli adagban $1 \mathrm{mg} / \mathrm{kg}, 3-4$ hét teljes dózis után megkezdhetô a csökkentése és 9-18 hónap után elhagyható. A glükokortikoidkezelés optimális időtartama a hosszú távú mellékhatások, az infekciós kockázat növekedése miatt továbbra is szakmai viták tárgyát képezi [13].

A ciklofoszfamid adható per os és intravénás bolusokban is, a két adagolási formát összehasonlítva egyformán hatékonynak bizonyultak, a pulzus-ciklofoszfamidkezelésnél alacsonyabb volt a kumulatív dózis, ami kisebb toxicitást jelent, azonban nagyobb a relapsus veszélye [14, 15]. Első vonalban adott iv. ciklofoszfamid hatástalansága esetén a per os adagolás még mindig lehet hatékony [16]. A ciklofoszfamid dózisát, a bolusok számát, az adagolás gyakoriságát a beteg állapotának, korának, vesefunkciójának, vérképének figyelembevételével kell megválasztani. Iv. adagolásnál a kezdő dózis $0,5-1,2 \mathrm{~g} / \mathrm{m}^{2}$ két, majd három hét múlva ismételve, később maximum 1 hónapra nyújtva az adagolás gyakoriságát. A francia protokollban a ciklofoszfamidbolus dózisa $0,6 \mathrm{~g} / \mathrm{m}^{2}$ az első három hétre, majd $0,7 \mathrm{~g} / \mathrm{m}^{2}$ három-négy hetenként adva, összdózis tekintetében ezek nagyjából egyenértékúek. Az EUVAS ajánlása szerint a ciklofoszfamid adható $15 \mathrm{mg} / \mathrm{kg}$ (maximum $1,2 \mathrm{~g}$ ) dózisban is, eleinte két, majd a negyedik infúziótól háromhetente, további 3-6 alkalommal [17, 18].

A nagy dózisú intravénás ciklofoszfamid toxicitása vesebetegekben, illetve idősekben magasabb lehet, de a dózis megfelelő csökkentésével hatékony és biztonságos kezelési lehetôség. Elengedhetetlen a megfelelő hidratáció ahhoz, hogy a ciklofoszfamid metabolitjainak, különösen az acroleinnek a hólyagtoxikus hatását kivédjük. Nátrium-2-mercapto-etánszulfonát (mesna) adása és 2-3 liter folyadék elfogyasztása javasolt a boluskezelés mellett.

Egy 293 beteg utánkövetésével végzett vizsgálat alapján a $>36$ g összdózisú ciklofoszfamid szignifikánsan növelte a nem melanoma típusú bőrdaganatok, a hólyagcarcinoma és a myeloid leukaemia kialakulásának kockázatát, az ennél alacsonyabb dózis csak a nem melanoma bőrdaganatokét fokozta, míg a ciklofoszfamidot nem kapó GPA-s betegnél nem észlelték a daganatok előfordulási gyakoriságának növekedését [19].

A per os ciklofoszfamiddózis $2 \mathrm{mg} / \mathrm{kg}$ naponta, bevétele reggel bő folyadékkal javasolt, és a folyamatos hidratációra egész nap figyelmet kell fordítani.

A ciklofoszfamid volt az évtizedek óta elfogadott indukciós szer, a legtöbb klinikus már nagy rutinnal alkalmazza, beleértve a mellékhatásainak kivédését és kezelését is, amelyet leginkább a kumulatív dózis okoz.

A rituximab, amely a B-lymphocyták felszínén található CD20 antigénhez kötődő, géntechnológiával előállított, egér/humán kiméra monoklonális antitest, glikozilált immunglobulin, ma már a ciklofoszfamidhoz hasonlóan hatékonynak bizonyult indukciós kezelési lehetőség, különösen relabáló, refrakter esetekben vagy a ciklofoszfamid kontraindikációja esetén. Azonban a RAVE és az EUVAS-RITUXVAS vizsgálatok alapján ANCA-pozitív GPA-ban, MPA-ban és renalis limitált vasculitisben a rituximab a remisszióindukcióban nem jobb, mint a ciklofoszfamid $[20,21]$. Ebben a két vizsgálatban a rituximabot szteroiddal együtt adták, 375 $\mathrm{mg} / \mathrm{m}^{2}$ dózisban 4 héten keresztül hetenként. Az infekciók előfordulási gyakorisága (főként bronchitis és pneumonia) nem volt gyakoribb, mint a ciklofoszfamidnál, és feltehetően a nagy dózisú kiegészítő szteroid hatásával lehetett összefüggésben. Vannak nem kontrollált prospektív vizsgálatok ANCA-negatív GPA-s betegek sikeres rituximabkezeléséról is [22], hangsúlyozva esetlegesen más antitestek, például a LAMP-2 és az endothelsejt elleni antitestek patogenetikai szerepét is [23], valamint a B-sejtek antitest-independens funkcióinak jelentőségét ezen betegségek kialakulásában. Néhány esetismertetés alapján azt a következtetést vonhatjuk le, hogy a rituximab hatékony a refrakter ANCA-pozitív és -negatív EGPA-ban, de további prospektív randomizált vizsgálatok szükségesek [24, 25]. 
Jelenleg nincs egyértelmü klinikai bizonyíték AAVben indukciós terápiaként a mikofenolát mofetil (MMF) hatékonyságára. Habár egy 35 kínai beteg bevonásával készült vizsgálat eredménye alapján generalizált betegség esetén alternatív szer lehet [26]. Jelenleg az MMF indukciós terápiaként csak vesemanifesztációk nélküli MPA-s betegeknél merül fel. Egy 140, GPA-s és MPA-s beteg bevonásával történt randomizált kontrollált vizsgálat folyik az MMF és ciklofoszfamid hatékonyságának összehasonlítására, a 6 hónapos előzetes adatok alapján az MMF nem jobb a remisszióindukcióban, mint az iv. ciklofoszfamid [27].

\section{MPA és EGPA rossz prognosztikai faktorok nélkül és a GPA lokalizált/korai szisztémás formái}

A diagnózis felállításakor rossz prognosztikai faktorral nem rendelkező (FFS = 0) MPA-s és EGPA-s betegek hatékonyan kezelhetők szteroiddal, és csak másodvonalban, perzisztens betegségaktivitáskor, illetve a glükokortikoidterápia melletti relapsus esetén van szükség immunszuppresszív szerekre.

A glükokortikoidok ajánlott kezdő dózisa $1 \mathrm{mg} / \mathrm{kg} /$ nap, 3-4 hétig teljes dózisban, majd fokozatosan csökkentve. A szteroiddal kezelt MPA-s vagy EGPA-s betegek relapsusrátája közel 50\%-os, de a 7 éves túlélési arány 79\%. A diagnózis felállításakor adott immunszuppresszív kezelés csökkentheti a relapsusokat, azonban a vizsgálatok eredményei szerint a ciklofoszfamid mellékhatásai ebben az esetben meghaladják a terápiás előnyt [28]. Olyan kevésbé toxikus szerek, mint az azathioprin kipróbálása a CHUSPAN 2 francia vizsgálat keretében folyamatban van.

Ellentétben az MPA-s és EGPA-s betegekkel, minden GPA-s beteget szteroid és immunszuppresszáns kombinált kezelésben kell részesíteni. Lokalizált vagy korai szisztémás formákban jön szóba a szteroid kombinálása methotrexattal. Az EUVAS NORAM vizsgálat alapján a methotrexat gyengébbnek bizonyult a relapsusok megelőzésében, mint a ciklofoszfamid, azonban ez részben a vizsgálat tervezésének is köszönhető, mert 12 hónap után a methotrexatot megvonták a betegektől [29]. Tehát ha az MTX effektív, akkor feltehetően évekig kell folytatni. Emellett nem randomizált vizsgálatok alapján feltételezhetjük, hogy a trimethoprim-szulfamethoxazol felső légúti manifesztációval járó, illetve lokalizált formájú GPA-s betegekben szintén alkalmas remisszióindukcióra és fenntartó kezelésre [30].

\section{Fenntartó kezelés}

Ha ciklofoszfamiddal sikerült remissziót elérnünk, akkor fenntartó kezelésként kevésbé toxikus immunszuppreszszánsra, azathioprinre vagy methotrexatra váltunk. Az AZA dózisa $2 \mathrm{mg} / \mathrm{kg}$ naponta, az MTX-é hetente 0,3 $\mathrm{mg} / \mathrm{kg}$, de maximum $25 \mathrm{mg}$ per os vagy subcutan alkalmazási formában. Nem bizonyított, hogy 3-6 hónapos ciklofoszfamiddal történt remisszióindukció után érdemes-e AZA-ra váltani vagy csak 12 hónap után [31]. A jelenlegi gyakorlat szerint 6 vagy 9 bolus, illetve 3-4 hónap után váltunk ciklofoszfamidról fenntartó terápiára [32].

A leflunomid az AZA és MTX alternatívája lehet; egy 54 , GPA-s beteget bevont vizsgálat $30 \mathrm{mg} / \mathrm{nap}$ leflunomid hatékonyságát vetette össze $20 \mathrm{mg}$ /hét dózisban adott MTX-szel, szignifikánsan magasabb relapsusrátát találtak ez utóbbi csoportban, ugyanakkor a leflunomidot szedőknél sokkal több volt a nemkívánatos esemény [33]. Egy tavaly megjelent review ismertette, hogy a nem biológiai fenntartó terápiák közül az MTX, az AZA és a leflunomid hasonló hatékonyságú [34]. További prospektív randomizált vizsgálatok szükségesek a leflunomid hatékonyságának bizonyítására.

A methotrexat és a leflunomid együttes adásának hatékonyságát vizsgálták minor relapsusban 43 GPA-s betegnél, 65\%-ban sikerült teljes remissziót elérniük, tehát az MTX-leflunomid kombináció lehetséges terápiás választási lehetőség fenntartó kezelésként [35].

Az IMPROVE vizsgálatban ciklofoszfamid indukciós terápiát követően napi $2 \mathrm{~g}$ MMF és napi $2 \mathrm{mg} / \mathrm{kg}$ AZA fenntartó hatékonyságát hasonlították össze 156 AAV-s betegben, az MMF-csoportban gyakoribbak voltak a relapsusok, a két csoportban nagyjából ugyanannyi volt a nemkívánatos esemény, emiatt az MMF csak azoknál a betegeknél jön szóba, akik nem tolerálják a szokásos fenntartó gyógyszereket.

Vizsgálatok folynak annak tisztázására, hogy a rituximab hatékony lehet-e a remisszió fenntartásában, és ha igen, milyen adagolással. A MAINRITSAN vizsgálat keretén belül a Francia Vasculitis Kutatócsoport végezte el az első prospektív randomizált kontrollált vizsgálatot, amely az RTX-et és az AZA-t hasonlította össze fenntartó hatékonyság szempontjából. A vizsgálat elsődleges végpontja a 28 hónapon belül bekövetkező major relapsusok száma volt (BVAS>10). A vizsgálatba 109, remiszsziót elért beteget vontak be. Az RTX-karba került betegek 6 havonta 500 mg RTX-et kaptak összesen 18 hónapig, az AZA-karba került betegek naponta $2 \mathrm{mg} / \mathrm{kg}$ gyógyszert szedtek. A 38,6 hónapos utánkövetés után az RTX-karba került betegek 12,7\%-ának, míg az AZA-karba került betegek 48,1\%-ának volt legalább egy major relapsusa, és az AZA-karban 3 beteg meghalt (infekció, malignitás és mesenterialis ischaemia volt a halálok), tehát az RTX fenntartó terápia előnyösebb az AZA-nál.

A RITAZAREM nemrég indult randomizált kontrollvizsgálat, szintén az RTX (4 havonta $1 \mathrm{~g}$ ) és az AZA ( $2 \mathrm{mg} / \mathrm{kg}$ naponta) hatékonyságát hasonlítja össze.

Egy 89 beteg bevonásával készült retrospektív vizsgálat eredménye alapján a rituximab hagyományos fenntartó szerekkel (azathioprin, methotrexat, mikofenolát mofetil) és glükokortikoidokkal kombinálva jobban 
csökkentette a relapsusrátát, mint ezek nélkül, ugyanakkor a mellékhatások gyakorisága nem emelkedett [36].

A BREVAS vizsgálat a belimumab humán monoklonális antitest hatékonyságát vizsgálja MPA-s és GPA-s betegek körében, napi $2 \mathrm{mg} / \mathrm{kg}$ AZA mellett kapnak a betegek placebót vagy iv. $10 \mathrm{mg} / \mathrm{kg}$ belimumabot a 0 , 14., 28. és ezt követően minden 28. napon a vizsgálat végéig - egyelőre egyik vizsgálat végleges eredményei sem kerültek publikálásra.

A fenntartó kezelés optimális időtartama bizonytalan. A relapsusok kétharmada a fenntartó kezelés megszakítását követően következik be, ha korábban a beteg 18-24 hónapig szedett gyógyszert. Az IMPROVE vizsgálatban a 39 hónapig követett betegek felének volt relapsusa. A folyamatban levő REMAIN vizsgálatban a betegek 2 vagy 4 évig $2 \mathrm{mg} / \mathrm{kg}$ dózisban AZA fenntartó kezelést kapnak, a vizsgálat eredményeiből valószínúleg számos kérdésünkre választ kaphatunk néhány év múlva. A relapsusok megbízható prediktorainak megismerése szintén segítheti majd a terápiás döntés meghozatalát, erre szintén vizsgálat van folyamatban.

\section{Kiegészítő kezelés}

Felmerül, hogy az ANCA gyors eltávolítása a keringésből előnyös lehet, különösen a súlyos állapotú betegeknél, azonban az, hogy a plazmaferézis milyen manifesztációknál jöhet szóba, például valóban előnyös-e egy tüdővérzésnél, még további vizsgálatok tárgyát kell, hogy képezze [37]. Más szerzők egyértelmúen előnyösnek tartják a plazmaferézist progresszív lefolyást mutató AAV-s betegeknél, 26 beteg bevonásával végzett kontrollált vizsgálatukban szignifikáns javulást észleltek a vesefunkcióban és a betegség kimenetele is kedvezőbb volt a feretizáltaknál [38]. A PEXIVAS randomizált kontrollált vizsgálat 500 beteg bevonásával vizsgálja jelenleg is a plazmaferézis és glükokortikoiddózisok szerepét AAV-s betegek kezelésében [39].

Az opportunista fertőzések, mint például a Pneumocystis jiroveci pneumonia elkerülése érdekében trimethoprim-szulfamethoxazol adása javasolt $960 \mathrm{mg}$ dózisban hetente háromszor a ciklofoszfamidkezelések adása alatt és 2-4 hónapig utána is, ugyanez megfontolandó a szteroidot és rituximabot kapó betegeknél is.

Minden, glükokortikoidot szedő betegnek megfelelő terápiában kell részesülnie a glükokortikoid indukálta osteoporosis megelőzésére, ráadásul a megfelelő $\mathrm{D}$-vitamin-pótlás immunregulatorikus hatása révén az autoimmun betegségek szupportív kezelésében is kedvező hatású [40].

A fájdalomcsillapítás, a felfekvések megelőzése, a fizioterápia kiemelkedő fontosságú mononeuritis multiplexes betegek esetén, ugyanígy az angiotenzinkonvertálóenzim-gátló vagy az angiotenzin-II-receptor-blokkoló bevezetése a renalis vasculitis következtében kialakuló hypertonia kezelésére.
Végezetül annak ellenére, hogy az utóbbi évtizedekben nagy fejlődés történt az ANCA-asszociált vasculitisek kezelésében (1. ábra) [11], még mindig sok AAV-s betegnél alakul ki végstádiumú veseelégtelenség. A dialízisdependens betegek túlélése lényegesen rosszabb, ezért a vesepótló kezelések közül törekedni kell a veseátültetésre, amely az eredmények alapján a beteg- és grafttúlélés szempontjából is kedvező. A veseátültetést leghamarabb a remisszió elérése után egy évvel ajánlatos elvégezni, az ANCA-pozitivitás nem jelent ellenjavallatot. A transzplantáció után megfelelő immunszuppreszszív kezelés mellett a relapsusráta viszonylag alacsony, amennyiben bekövetkezik, ciklofoszfamid, illetve rituximab adása jön szóba, a hatékonyság és biztonságosság vizsgálata ilyen relációban még folyamatban van [41].

Anyagi támogatás: A közlemény anyagi támogatásban nem részesült.

Szerzői munkamegosztás: Sz. M. Zs.: Összefoglaló közlemény megírása. P. P.: 1., 2. táblázat, B. A.: 3. táblázat elkészítése. P. Gy., K. E.: A kézirat szakmai véleményezése. A kézirat végleges változatát valamennyi szerző elolvasta és jóváhagyta.

Érdekeltségek: A szerzőknek nincsenek érdekeltségeik.

\section{Irodalom}

[1] Jennette, J. C., Falk, R. J., Bacon, P. A., et al.: 2012 revised International Chapel Hill Consensus Conference nomenclature of vasculitides. Arthritis Rheum., 2013, 65(1), 1-11.

[2] http://www.irgalmas.hu/c/document_library/get file? uuid $=0587 \mathrm{lb} 49-\mathrm{bcf} 4-424 \mathrm{~d}-\mathrm{b} 5 \mathrm{bb}-6520 \mathrm{~b} 19 \mathrm{dc} 768 \&$ groupId $=10230$

[3] Fauci, A. S., Haynes, B., Katz, P.: The spectrum of vasculitis: clinical, pathologic, immunologic and therapeutic considerations. Ann. Intern. Med., 1978, 89(5 Pt 1), 660-676.

[4] Flossmann, O., Berden, A., de Groot, K., et al.: Long-term patient survival in ANCA-associated vasculitis. Ann. Rheum. Dis., 2011, $70(3), 488-494$

[5] Guillevin, L., Lhote, F., Gayraud, M., et al.: Prognostic factors in polyarteritis nodosa and Churg-Strauss syndrome. A prospective study in 342 patients. Medicine, 1996, 75(1), 17-28.

[6] Gayraud, M., Guillevin, L., le Toumelin, P., et al.: Long-term followup of polyarteritis nodosa, microscopic polyangitis, and Churg-Strauss syndrome: analysis of four prospective trials including 278 patients. Arthritis Rheum., 2001, 44(3), 666-675.

[7] Guillevin, L., Pagnoux, C., Seror, R., et al.: The Five-Factor Score revised: assessment of prognoses of systemic necrotizing vasculitides based on the French Vasculitis Study Group (FVSG) cohort. Medicine, 2011, 90(1), 19-27.

[8] Luqmani, R. A., Exley, A. R., Kitas, G. D., et al.: Disease assessment and management of the vasculitides. Baillieres Clin. Rheumatol., 1997, 11(2), 423-446.

[9] Stone, J. H., Hoffmann, G. S., Merkel, P. A., et al.: A disease-specific activity index for Wegener's granulomatosis: modification of the Birmingham Vasculitis Activity Score. International Network for the Study of the Systemic Vasculitides (INSSYS). Arthritis Rheum., 2001, 44(4), 912-920. 
[10] Mukbtyar, C., Lee, R., Brown, D., et al.: Modification and validation of the Birmingham Vasculitis Activity Score (version 3). Ann. Rheum. Dis., 2009, 68(12), 1827-1832.

[11] Ntatsaki, E., Carruthers, D., Chakravarty, K., et al.: BSR and BHPR guideline for the management of adults with ANCA-associated vasculitis. Rheumatology (Oxford), 2014, 53(12), 23062309.

[12] Hellmich, B., Flossmann, O., Gross, W. L., et al.: EULAR recommendations for conducting clinical studies and/or clinical trials in systemic vasculitis: focus on anti-neutrophil cytoplasm antibody-associated vasculitis. Ann. Rheum. Dis., 2007, 66(5), 605617

[13] Walsh, M., Merkel, P. A., Mahr, A., et al.: Effects of duration of glucocorticoid therapy on relapse rate in antineutrophil cytoplasmic antibody-associated vasculitis: A metaanalysis. Arthritis Care Res., 2010, 62(8), 1166-1173.

[14] Guillevin, L., Cordier, J. F., Lhote, F., et al.: A prospective, multicenter, randomized trial comparing steroids and pulse cyclophosphamide versus steroids and oral cyclophosphamide in the treatment of generalized Wegener's granulomatosis. Arthritis Rheum., 1997, 40(12), 2187-2198.

[15] De Groot, K., Harper, L., Jayne, D. R., et al.: Pulse versus daily oral cyclophosphamide for induction of remission in antineutrophil cytoplasmic antibody-associated vasculitis: a randomized trial. Ann. Intern. Med., 2009, 150(10), 670-680.

[16] Seror, R., Pagnoux, C., Ruivard, M., et al.: Treatment strategies and outcome of induction-refractory Wegener's granulomatosis or microscopic polyangiitis: analysis of 32 patients with first-line induction-refractory disease in the WEGENT trial. Ann. Rheum. Dis., 2010, 69(12), 2125-2130.

[17] Adu, D., Pall, A., Luqmani, R. A., et al.: Controlled trial of pulse versus continuous prednisolone and cyclophosphamide in the treatment of systemic vasculitis. QJM, 1997, 90(6), 401-409.

[18] Rihova, Z., Jancova, E., Merta, M., et al.: Daily oral versus intravenous cyclophosphamide in the therapy of ANCA-associated vasculitis - preliminary single center experience. Prague Med. Rep., 2004, 105(1), 64-68.

[19] Faurschou, M., Mellemkjaer, L., Voss, A., et al.: Prolonged risk of specific malignancies following cyclophosphamide therapy among patients with granulomatosis with polyangitis. Rheumatology (Oxford), 2015, 54(8), 1345-1350.

[20] Stone, J. H., Merkel, P. A., Spiera, R., et al.: Rituximab versus cyclophosphamide for ANCA-associated vasculitis. N. Engl. J. Med., 2010, 363(3), 221-232.

[21] Jones, R. B., Tervaert, J. W., Hauser, T., et al.: Rituximab versus cyclophosphamide in ANCA-associated renal vasculitis. N. Engl. J. Med., 2010, 363(3), 211-220.

[22] Khan, A., Lawson, C. A., Quinn, M. A., et al.: Successful treatment of ANCA-negative Wegener's granulomatosis with rituximab. Int. J. Rheumatol., 2010, 2010, 846063.

[23] Chen, M., Kallenberg, C. G., Zhao, M. H.: ANCA-negative pauciimmune crescentic glomerulonephritis. Nat. Rev. Nephrol., $2009,5(6), 313-318$

[24] Cartin-Ceba, R., Keogh, K. A., Specks, U., et al.: Rituximab for the treatment of Churg-Strauss syndrome with renal involvement. Nephrol. Dial. Transplant., 2011, 26(9), 2865-2871.

[25] Thiel, J., Hössler, F., Salzer, U., et al.: Rituximab in the treatment of refractory or relapsing eosinophilic granulomatosis with polyangiitis (Churg-Strauss syndrome). Arthritis Res. Ther., 2013, 15(5), Rl33.

[26] Hu, W., Liu, C., Xie, H., et al.: Mycophenolate mofetil versus cyclophosphamide for inducing remission of ANCA vasculitis with moderate renal involvement. Nephrol. Dial. Transplant., 2008, 23(4), 1307-1312.
[27] Jones, R., Harper, L., Ballarin, J., et al.: A randomized trial of mycophenolate mofetil versus cyclophosphamide for remission induction in ANCA-associated vasculitis. Presse Med., 2013, 42(4), 678-679. J. Am. Soc. Nephrol., 2012, 23, 3B

[28] Ribi, C., Cohen, P., Pagnoux, C., et al.: Treatment of ChurgStrauss syndrome without poor-prognosis factors: a multicenter, prospective, randomized, open-label study of seventy-two patients. Arthritis Rheum., 2008, 58(2), 586-594.

[29] De Groot, K., Rasmussen, N., Bacon, P. A., et al.: Randomized trial of cyclophosphamide versus methotrexate for induction of remission in early systemic antineutrophil cytoplasmic antibodyassociated vasculitis. Arthritis Rheum., 2005, 52(8), 2461-2469.

[30] Stegeman, C. A., Tervaert, J. W., de Jong, P. E., et al.: Trimethoprim-sulfamethoxazole (co-trimoxazole) for the prevention of relapses of Wegener's granulomatosis. N. Engl. J. Med., 1996, 335(1), 16-20.

[31] Walsh, M., Faurschou, M., Berden, A., et al.: Long-term follow-up on cyclophosphamide compared with azathioprine for initial maintenance therapy in ANCA-associated vasculitis. Clin. J. Am. Soc. Nephrol., 2014, 9(9), 1571-1576.

[32] Jayne, D., Rasmussen, N., Andrassy, K., et al.: A randomized trial of maintenance therapy for vasculitis associated with antineutrophil cytoplasmic autoantibodies. N. Engl. J. Med., 2003, 349(1), 36-44.

[33] Metzler, C., Miehle, N., Manger, K., et al.: Elevated relapse rate under oral methotrexate versus leflunomide for maintenance of remission in Wegener's granulomatosis. Rheumatology (Oxford), 2007, 46(7), 1087-1091.

[34] Hazlewood, G. S., Metzler, C., Tomlinson, G. A., et al.: Non-biologic remission maintenance therapy in adult patients with ANCA-associated vasculitis: A systematic review and network meta-analysis. Joint Bone Spine, 2014, 81(4), 337-341.

[35] Bremer, J. P., Ullrich, S., Laudien, M., et al.: Methotrexate plus leflunomide for the treatment of relapsing Wegener's granulomatosis. A retrospective uncontrolled study. Clin. Exp. Rheumatol., 2010, 28(1 Suppl. 57), 67-71.

[36] Azar, L., Springer, J., Langford, C. A., et al.: Rituximab with or without a conventional maintenance agent in the treatment of relapsing granulomatosis with polyangiitis (Wegener's): a retrospective single-center study. Arthritis Rheumatol., 2014, 66(10), 2862-2870.

[37] Walsh, M., Catapano, F., Szpirt, W., et al.: Plasma exchange in antineutrophil cytoplasm antibody-associated vasculitis. Curr. Opin. Nephrol. Hypertens., 2014, 23(6), 555-559.

[38] De Joode, A. A., Sanders, J. S., Smid, W. M., et al.: Plasmapheresis rescue therapy in progressive systemic ANCA-associated vasculitis: single-center results of stepwise escalation of immunosupression. J. Clin. Apher., 2014, 29(5), 266-272.

[39] Walsh, M., Merkel, P. A., Peh, C. A., et al.: Plasma exchange and glucocorticoid dosing in the treatment of anti-neutrophil cytoplasm antibody associated vasculitis (PEXIVAS): protocol for rendomized controlled trial. Trials, 2013, 14, 73.

[40] Takács, I., Benkö, I., Toldy, E., et al.: Hungarian consensus regarding the role of vitamin $\mathrm{D}$ in the prevention and treatment of diseases. [Hazai konszenzus a D-vitamin szerepéról a betegségek megelőzésében és kezelésében.] Orv. Hetil., 2012, 153(Suppl.), 5-26. [Hungarian]

[41] Hruskova, Z., Geetha, D., Tesar, V.: Renal transplantation in antineutrophil cytoplasmic antibody-associated vasculitis. Nephrol. Dial. Transplant., 2015, 30(Suppl. 1), il59-i163.

(Szabó Melinda Zsuzsanna dr., Budapest, Frankel Leó út 38-40., 1023 e-mail: szabo.melinda@orfi.hu) 